\title{
KONSTRUKSI HUKUM DAN METODE INTERPRETASI HUKUM
}

\author{
Oleh : H. Enju Juanda, S.H., M.H.")
}

\begin{abstract}
The main source of law in Indonesia is the national legal system of legislation or a written system, while the legislation is static while the community is dynamic, so that the legislation is often left behind by the development community.

In connection with the above mentioned problems the judge (court) can undertake the construction of law and legal interpretations.
\end{abstract}

\begin{abstract}
ABSTRAK
Sumber hukum utama dalam sistem hukum nasional Indonesia adalah Peraturan Perundang-undangan atau sistem tertulis, sedangkan Peraturan Perundang-undangan bersifat statis sementara masyarakat bersifat dinamis, sehingga seringkali Peraturan Perundang-undangan tertinggal oleh perkembangan masyarakat artinya peristiwa yang terjadi dalam masyarakat pengaturannya tidak terdapat dalam peraturan perundang-undanganyang berlaku.

Sehubungan dengan persoalan tersebut di atas, maka hakim ( Pengadilan) dalam meyelesaikan peristiwa hukum yang terjadi dalam masyarakat, tetapi pengaturannya tidak ada dalam peraturan perundang-undangan yang berlaku dapat melakukan konstruksi hukum dan interpretasi hukum.
\end{abstract}

\footnotetext{
*) Dosen Fakultas Hukum Universitas Galuh
} 


\section{Pendahuluan}

Bahwasannya untuk menyelesaikan suatu persoalan yang konkrit terjadi dalam masyarakat agar terjadi ketertiban berdasarkan keadilan dan kepastian hukum, maka seyogiyanya kita mengetahui sumber hukumnya untuk dijadikan dasar sebagai pedoman untuk menyelesaikan persoalan tersebut. Yang dimaksud dengan sumber hukum adalah segala apa saja yang menimbulkan aturan-aturan yang mempunyai kekuatan yang bersifat memaksa yakni aturanaturan yang kalau dilanggar mengakibatkan sanksi yang tegas dan nyata.

Menurut Ilmu Hukum, sumber hukum dapat dibagi menjadi dua yaitu sumber hukum dalam arti materil dan sumber hukum dalam arti formil. Adapun yang dimaksud sumber hukum dalam arti materil adalah faktor-faktor yang menentukan isi hukum atau sebagai jawaban terhadap pertanyaan mengapa seseorang mentaati hukum, sumber hukum materil dapat berupa antara lain Ideologi, Politik, Ekonomi, Sosial dan Budaya, Pertahanan dan Keamanan.

Sedangkan yang dimaksud dengan sumber hukum dalam arti formil adalah faktor-faktor yang mendorong terbentuknya atau terwujudnya hukum atau sebagai jawaban terhadap pertanyaan dimanakah kita menemukan ketentuan hukum untuk menyelesaikan persoalan yang konkrit yang terjadi dalam masyarakat. Sumber Hukum dalam arti formal dapat berupa Undang-undang, Kebiasaan dan Adat, Perjanjian dan Traktat, Keputusan-keputusan Pengadilan atau Yurisprudensi, Pendapat Sarjana Hukum atau Doktrin.

Menurut Mochtar Kusumaatmaja dalam salah satu bukunya menyebutkan bahwa sumber utama dalam sistem hukum nasional Indonesia adalah undangundang atau perundang-undangan, disusul dengan kebiasaan dan keputusan pengadilan, pertanyaan yang kemudian timbul dalam kehidupan praktis adalah bagaimana kita menerapkan hukum positif.

Mengenai undang-undang sebagai sumber utama hukum nasional Indonesia ini, ada satu asas yang perlu diketahui yaitu asas yang mengatakan bahwa "setiap orang dianggap mengetahui undang-undang" itu adalah suatu fiksi atau khalayan.

Suatu peraturan perundang-undangan bersifat statis sedangkan masyarakat bersifat dinamis, sehingga seringkali peraturan perundang-undangan tertinggal oleh perkembangan masyarakat, sementara itu hakim tidak boleh menolak untuk menyelesaikan persoalan yang diajukan kepadanya untuk 
diselesaikan, hal itu sebagaimana berdasarkan ketentuan Pasal 10 ayat (1) Undang-Undang Republik Indonesia Nomor 48 Tahun 2009 tentang Kekuasaan Kehakiman yang menentukan bahwa :

Pengadilan dilarang menolak untuk memeriksa, mengadili, dan memutus suatu perkara yang diajukan dengan dalih bahwa hukum tidak ada atau kurang jelas, melainkan wajib untuk memeriksa dan mengadilinya

Sehingga dengan demikian berdasarkan ketentuan tersebut di atas hakim berkewajiban untuk memutuskan persoalan yang diajukan kepadanya dengan jalan sebagaimana ditetapkan dalam ketentuan Pasal 5 ayat (1) Undang-Undang Republik Indonesia Nomor 48 Tahun 2009 tentang Kekuasaan Kehakiman menentukan bahwa :

Hakim dan Hakim Konstitusi wajib menggali, mengikuti, dan memahami nilai-nilai hukum dan rasa keadilan yang hidup dalam masyarakat.

Berdasarkan ketentuan tersebut di atas jelas bahwa pengadilan mempunyai kedudukan penting dalam sistem hukum negara Kesatuan Republik Indonesia, karena Pengadilan melakukan fungsi yang pada hakikatnya melengkapi ketentuan-ketentuan hukum tertulis melalui pembentukan hukum (rechtsvorming) dan penemuan hukum (rechtsvinding). Dengan perkataan lain hakim/pengadilan dalam sistem hukum Indonesia yang pokoknya mengutamakan yang tertulis itu mempunyai fungsi membuat hukum baru (creation of new law). Karena itu sistem hukum Indonesia, walaupun merupakan sistem hukum tertulis, namun merupakan sistem yang terbuka (open system).

Yudha Bhakti Ardiwisastra menjelaskan bahwa apabila pengertian hukum diartikan secara terbatas sebagai keputusan penguasa dan dalam arti yang lebih terbatas lagi sebagai keputusan hakim (Pengadilan) yang menjadi pokok masalah adalah tugas dan kewajiban hakim dalam menemukan apa yang dapat menjadi hukum, sehingga melalui keputusannya hakim dapat dianggap sebagai salah satu faktor pembentuk hukum.

Selanjutnya Yudha Bhakti Ardhiwisastra menyatakan bahwa jadi tugas penting dari hakim ialah menyesuaikan Undang-undang dengan hal-hal nyata di masyarakat. Apabila Undang-undang tidak dapat dijalankan menurut arti katanya hakim harus menafsirkannya. Dengan lain perkataan apabila Undang-undang tidak jelas, hakim wajib menafsirkannya sehingga ia dapat membuat suatu keputusan yang adil dan sesuai dengan maksud yaitu mencapai kepastian 
hukum. Karena itu orang dapat mengatakan bahwa menafsirkan Undang-undang adalah kewajiban hukum dari Hakim.

\section{Pembahasan}

\section{Konstruksi Hukum}

Untuk memenuhi kewajiban hakim dalam mengisi kekosongan hukum atau ketidakjelasan suatu peraturan perundangan-undangan dalam ilmu hukum dikenal dengan Konstruksi Hukum dan Interpretasi (Penafsiran).

Kontruksi (Rekayasa) Hukum adalah cara mengisi kekosongan peraturan perundang-undangan dengan asas-asas dan sendi-sendi hukum. Konstruksi (Rekayasa Hukum) terdiri dari 3 (tiga) bentuk yaitu analogi (abstraksi), Determinasi (Penghalusan Hukum) dan Argumentasi A contrario.

1. Analogi adalah penerapan sesuatu ketentuan hukum bagi keadaan yang pada dasarnya sama dengan keadaan yang secara eksplisit diatur dengan ketentuan hukum tersebut tadi, tetapi penampilan atau bentuk perwujudannya (bentuk hukum) lain. Contoh : Menurut Pasal 1576 Kitab Undang-undang Hukum Perdata yang mengatakan bahwa jual beli tidak memutuskan sewa menyewa.

Ketentuan tersebut berarti bahwa apabila suatu rumah dipindahtangankan dengan transaksi jual beli antara si pemilik rumah $A$ dengan pembeli rumah B maka perjanjian sewa menyewa yang telah diadakan antara si pemilik lama (A) dengan si penyewa (C) tetap berlaku, artinya transaksi jual beli rumah antara $A$ dan $B$ tidak mengakibatkan batalnya perjanjian sewa menyewa antara $A$ dengan $C$. Ketentuan tersebut berlaku juga terhadap perbuatan tukar menukar, hibah, hadiah, dan pewarisan. Karena perbuatan tersebut mengandung kesamaan dengan jual beli yaitu mengakibatkan beralihnya hak milik.

2. Penghalusan hukum yaitu dengan tidak menerapkan atau menerapakan hukum secara lain daripada ketentuan hukum tertulis yang ada atau memperlakukan hukum sedemikian rupa (secara halus) sehingga seolaholah tidak ada pihak yang disalahkan.

Contoh :

- Di suatu jalan terjadi tabrakan antara kendaraaan yang dikemudikan $B$, akibat tabrakan tersebut kendaraan $\mathrm{A}$ dan $\mathrm{B}$ sama-sama rusak. Apabila $\mathrm{A}$ 
menuntut ganti rugi terhadap $B$, maka $B$ juga dapat menuntut ganti rugi terhadap $A$, oleh karena keduanya salah dalam menjalankan kendaraannya maka sama-sama harus saling memberi ganti rugi sehingga terjadi suatu kompensasi antara keduanya.

- Sebuah delman melewati persimpangan jalan dengan rel kereta api. Tabrakan terjadi dalam keadaan pintu kereta api tidak tertutup karena penjaga pintu kereta api itu tertidur dan delman lewat saja karena kusirnya mengantuk. Berdasarkan penghalusan hukum penjaga pintu dan kusir delman diputuskan salah semua.

3. Argumentum a contrario adalah ungkapan pengingkaran terhadap hal yang sebaliknya misalnya dalam hukum perkawinan ada ketentuan bahwa seorang wanita yang telah bercerai dari suaminya, tidak diperbolehkan melaksanakan pernikahan dengan laki-laki lain sebelum lewatnya 300 hari, ketentuan tersebut tidak berlaku bagi seorang laki-laki.

Pelaksanaan Konstruksi Hukum oleh Hakim, dalam Pengadilan Indonesia Yudha Bhakti Ardhiwisastra memberikan contoh sebagai berikut : Berdasarkan Surat Permohonan dari Pemohon Iwan Robianto Iskandar (Seorang laki-laki) kepada Pengadilan Negeri Jakarta Selatan dan Barat pada tanggal 03 September 1973 agar Pemohon dapat diganti dan diubah status hukumnya dari seorang pria yang bernama Iwan Robianto Iskandar menjadi Vivian Rubyanti Iskandar, seorang wanita. Permohonan pertama ini kemudian diubah oleh permohonan kedua pada tanggal 01 Oktober 1973 dengan mengubah petitum permohonannya, sebagai berikut : (Putusan Pengadilan yang berupa Ketetapan ini disarikan dari Bismar Siregar, Keadilan Hukum Dalam Berbagai Aspek Hukum Nasional, CV. Rajawali, Jakarta, 1986, hlm. 185-196).

1) Agar Pemohon semenjak tanggal 28 Juni 1973 disahkan sebagai seorang wanita;

2) Agar berdasarkan Pasal 93 dari Peraturan Catatan Sipil untuk golongan Tionghoa (Stb. 1926 No. 558), Pemohon diberi izin untuk mengganti namanya sendiri (iegennaam) dari Iwan Robianto (Iskandar);

3) Agar berdasarkan Pasal 94 dari Peraturan Tersebut Pengadilan menyampaikan keputusannya kepada Pegawai Catatan Sipil untuk 
golongan Tionghoa di Jakarta supaya didaftarkan dan dicatat pada pinggir Akta Kelahiran yang bersangkutan.

Penggantian nama dari Iwan Robianto (Iskandar) sebagai seorang Pria, menjadi nama Vivian Rubyanti (Iskandar) sebagai seorang wanita.

Setelah mempelajari dan mempertimbangkan surat-surat bukti dan saksi ahli yang diajukan oleh Pemohon di persidangan, dalam pertimbangan hukumnya Pengadilan mengemukakan alasan-alasan sebagai berikut :

1) Perubahan status seseorang yang pada waktu itu dikenal dengan istilah penggantian kelamin, hal itu ditinjau dari segi hukumnya merupakan sesuatu yang sangat besar pengaruhnya terhadap perkembangan di dalam masyarakat, karena ;

a. peristiwa perubahan status ini merupakan persoalan baru dalam masyarakat,

b. hal ini belum diatur oleh undang-undang, karena pembuat undangundang waktu itu tidak atau belum memperkirakan terjadinya hal-hal seperti itu,

c. dalam hukum diperlukan suatu penegasan status seorang wanita atau laki-laki, karena penentuan status demikian itu diperlukan baik dalam Hukum Perdata misalnya apabila seseorang akan menikah, dalam hal warisan, dalam perjanjian kerja dan lain-lain maupun dalam Hukum Pidana,

d. undang-undang hanya mengenal istilah laki-laki atau perempuan.

2) Tidak adanya undang-undang atau asas hukum bagi Pengadilan tentang perubahan status ini tidak saja diperlukan bagi diri pemohon, tetapi penting sekali dalam hukum, baik dalam Hukum Perdata maupun dalam Hukum Pidana seperti tersebut di atas. Pengadilan akan menunjuk pada asas hukum secara umum, yaitu :

a. setiap orang berhak mengajukan perkara-perkara di Pengadilan mengenai hal-hal yang diatur maupun yang tidak diatur oleh suatu undang-undang,

b. hakim Pengadilan Negeri adalah hakim sehari-hari dari lingkungan Peradilan Umum yang berarti, bahwa setiap orang mengenai halhalnyayang timbul dalam kehidupan sehari-hari dalam masyarakat berhak memohon perlindungan hukum baginya, 
c. apabila terhadap soal yang menjadi persoalan itu belum ada peraturan hukumnya, Hakim harus mem-beri putusan yang selaras dengan susunan hukum adat, harus memberikan putusan berdasar kenya-taan sosial yang hidup dalam masyarakat,

d. merupakan kenyataan sosial yang hidup dalam masyarakat bahwa diantara dua jenis mahluk Illahi ini laki-laki dan perempuan terdapat pula segolongan orang yang hidupnya diantara kedua mahluk tersebut di atas,

e. perkembangan ilmu pengetahuan khususnya di bidang ilmu kedokteran telah memungkinkan pada seseorang itu untuk dapat disempurnakan jenisnya, dapat digolongkan sebagai laki-laki atau wanita,

f. adanya kenyataan bahwa tidak semua wanita itu dilahirkan sempurna, karena ada wanita yang sejak lahirnya tidak mempunyai peranakan, indung telur, tetapi wanita tersebut tetap disebut juga sebagai wanita,

g. bahwa agama pun (Kristen Protestan), memboleh-kan penyempurnaan kelamin yang dilakukan oleh ilmu pengetahuan kedokteran tersebut, apabila ini merupakan satu-satunya jalan untuk menolong penderitaan seseorang agar dapat hidup sebagai manusia yang wajar.

3) Dalam perkara ini Ketetapan Hakim hanya bersifat dekla-ratoir tidak bersifat konstitutif, karena dalam perkara ini Hakim hanya menyelidiki apakah benar setelah operasi ini telah terjadi hal-hal yang diuraikan dalam permohonan.

Setelah menyadari berbagai pertimbangan yang pokok, baik berdasarkan pertimbangan asas hukum maupun pertimbangan berdasarkan saksi ahli (tim dokter ahli), saksi-saksi lainnya (saksi a charge), pendeta agama Protestan, Pengadilan mengabulkan permohonan Pemohon untuk dinyatakan sebagai wanita dan memberi izin kepada Pemohon untuk mengganti namanya dari Iwan Rubianto (Iskandar) menjadi Vivian Rubyanti Iskandar setelah akta kelahiran Pemohon diubah. Ketetapan Pengadilan ini dibuat pada hari Rabu tanggal 14 November 1973. 
Dari kasus Vivian Rubyanti ini kiranya dapat diambil beberapa hal penting bagi pengembangan ilmu hukum dalam praktek di Indonesia. Dilihat dari segi ilmu hukum seluk-beluk ganti keiamin masih merupakan persoalan baru di bidang perkembangan hukumnya. Adanya kepentingan persoalan hukum muncul setelah adanya perkembangan di bidang ilmu kedokteran yang disebut operasi kelamin. Adanya Penetapan pengadilan Negeri Jakarta Barat dan Selatan No. 546/73. P tertanggal 14 November 1973 tersebut sebagai suatu era baru di bidang praktek pengadilan di Indonesia dalam mengisi tetosongan peraturan hukum. Di dalam diktum pertimbangan hrtumnya, Pengadilan menyadari bahwa memang peristiwa perubahan status ini belum diatur oleh undang-undang, iarena pembuat undang-undang waktu itu tidak atau belum memperkirakan akan terjadinya hal-hal seperti itu. (Perhatikan Ketentuan Pasal 14 ayat (1) Undang-undang Nomor 14 Tahun 1970 seperti telah dijelaskan di muka)

Apabila terhadap soal yang menjadi persoalan itu belum ada peraturan hukumnya, Pengadilan pun menyadari bahwa a harus memberi putusan yang selaras dengan susunan nukum adat, harus memberikan putusan berdasarkan kenya-taan sosial yang hidup dalam masyarakat. Kenyataan sosial telah membuktikan bahwa diantara dua jenis makhluk Tuhan yaitu laki-laki dan perempuan terdapat pula segolongan orang yang hidupnya diantara kedua makhluk tersebut. (Perhatikan maksud ketentuan Pasal 27 ayat (1) Undang-undang Nomor 14 Tahun 1970).

Dalam mengisi kekosongan hukum tentang perubahan kelamin itu pertimbangan penetapan Pengadilan juga menin-jau dari segi agama yang disesuaikan dengan keyakinan si Pemohon yaitu bahwa perubahan kelamin tidak bertentangan dengan Agama Kristen Protestan. Hal demikian ini dijadikan bahan pertimbangan hukum oleh hakim setelah mendengar saksi Eka Dharmaputra, seorang pendeta agama Protestan dari Dewan Gereja Indonesia (DGl) yang dibawah sumpah pada pokoknya sependapat, bahwa Gereja tidak berkeberatan apabila perubahan kelamin itu hanya satu-satunya jalan untuk menolong 
penderitaan si Pemohon sehingga ia dapat hidup berkembang sebagai manusia yang wajar.

\section{Interpretasi atau Penafsiran Hukum}

Interpretasi atau penafsiran adalah cara mencari arti dan makna suatu peraturan perundang-undangan. Penafsiran dapat dilakukan antara lain :

1. Interpretasi bahasa atau tata bahasa : (grammatikale intepretatie). Di sini ketentuan atau kaidah hukum (tertulis) diartikan menurut arti kalimat atau bahasa sebagaimana diartikan oleh orang biasa yang menggunakan bahasa secara biasa (sehari-hari). "Peralatan rumah tangga" dan "alat angkutan" misalnya harus diartikan secara wajar dalam hubungannya dengan perkara yang diperiksa pengadilan. Ini tidak menghalangi kemungkinan penggunaan istilah yang lebih teknis bila hal itu diperlukan.

Contoh : kendaraan (air) :

Segala alat angkutan orang atau barang, yang bergerak dari suatu tempat ke tempat lain di atas atau di bawah permukaan air.

2. Penafsiran Historis atau sejarah

Penafsiran cara ini adalah meneliti sejarah daripada undang-undang yang bersangkutan. Penafsiran historis ini adalah 2 macam :

a. Penafsiran menurut sejarah pembuatan undang-undang (wetshistorische interpretatie).

Penafsiran wetshistorische ini juga dinamakan penafsiran sempit dan hanya menyelidiki "apakah maksud pembuat undang-undang dalam menetapkan peraturan perundang-undangan itu atau siapa yang membuat rancangan untuk undang-undang, apa dasar-dasarnya, apa yang diperdebatkan dalam sidang-sidang DPR dan sebagainya sehingga undang-undang itu dapat ditetapkan secara resmi.

b. Penafsiran menurut sejarah hukum (Rechtshistorische Interpretatie).

Penafsiran historis ini dinamakan penafsiran yang luas, karena penafsiran wetshistorisch termasuk di dalamnya. Penafsiran menurut sejarah hukum ini menyelidiki apakah asal-usul peraturan itu dari suatu sistem hukum yang dahulu pernah berlaku atau dari sistem hukum lain yang sekarang masih berlaku atau dari sistem hukum lain yang sekarang masih berlaku di negara lain, misalnya KUH Perdata yang berasal dari 
Burgerlijk Wetboek (BW) Negeri Belanda. BW ini berasal dari Code Civil Prancis atau Code Napoleon. Masuknya Code Civil Prancis ke Negeri Belanda (BW) berdasarkan asas kankordansi sama halnya dengan masuknya BW Negeri Belanda ke Indonesia sebagai negara jajahan.

3. Penafsiran Sistematis

Yang dimaksud dengan penafsiran sistematis, ialah suatu penafsiran yang menghubungkan pasal yang satu dengan pasal yang lain dalam suatu perundang-undangan yang bersangkutan atau pada perundang-undangan hukum lainnya, atau membaca penjelasan suatu perundang-undangan, sehingga kita mengerti apa yang dimaksud.

Contoh :

- Pasal 1330 KUH Perdata mengemukakan tidak cakap untuk membuat perjanjian antara lain orang-orang yang belum dewasa.

Untuk mengetahui pengertian orang dewasa kita dapat melihat ketentuan Pasal $330 \mathrm{KUH}$ Perdata yang memberikan batas belum berumur 21 tahun, akan tetapi meskipun belum berumur 21 tahun apabila telah kawin orang tersebut dikualifikasikan telah dewasa.

Jadi dalam hal ini ketentuan Pasal 1330 KUH Perdata ditafsirkan secara sistematis dengan ketentuan Pasal 330 KUH Perdata.

4. Penafsiran Sosiologis

Penafsiran sosiologis ialah penafsiran yang disesuaikan dengan keadaan masyarakat. Penafsiran sosiologis adalah penafsiran yang disesuaikan dengan keadaan sosial yang di dalam masyarakat agar penerapan hukum dapat sesuai dengan tujuannya ialah kepastian hukum berdasarkan asas keadilan masyarakat.

Contoh penafsiran sosiologis :

- Dalam pasal 362 KUH Pidana, ditegaskan larangan untuk mencuri barang kepunyaan orang lain.

Bunyi pasal 362 KUH Pidana sebagai berikut "Barangsiapa mengambil sesuatu barang yang sama sekali atau sebagian termasuk kepunyaan orang lain, dengan maksud akan memiliki barang itu dengan melawan hak, dihukum karena pencurian dengan hukuman penjara selamalamanya lima tahun atau denda sebanyak-banyaknya Rp. 900." 
Apakah yang dimaksud dengan barang itu ? Mula-mula pengertian barang ialah segala yang bisa dilihat, diraba dan dirasakan secara riil. Waktu itu listrik tidak termasuk sebagai barang dan pencuri listrik tidak dapat dihukum berdasarkan pasal 362 KUH Pidana. Kemudian penafsiran sosiologis berlaku terhadap listrik yang dianggap sebagai barang, karena listrik itu mempunyai nilai. Untuk mengadakan proyek perlistrikan diperlakukan penafsiran sosiologis atas listrik, maka siapa yang mengkait kabel listrik PLN di jalan, dapat dikatakan melakukan pencurian dan berlaku pasal 362 KUH Pidana.

5. Penafsiran Otentik

Penafsiran otentik atau penafsiran secara resmi (authentieke interpretatie atau officieele interpretatie) ialah penafsiran secara resmi.

Penafsiran yang dilakukan oleh Pembuat Undang-Undang sendiri dapat diikuti dalam penjelasan Undang-Undang sebagai lampiran dan tambahan Lembaran Negara dari Undang-Undang yang bersangkutan.

6. Penafsiran Perbandingan

Penafsiran perbandingan ialah suatu penafsiran dengan membandingkan antara hukum lama dengan hukum positif yang berlaku saat ini, antara hukum nasional dengan hukum asing dan hukum kolonial.

- Hukum lama dengan hukum positif yang berlaku saat ini, mungkin hukum lama cocok untuk diterapkan lagi pada masa sekarang ini. Umpamanya beberapa hukum dan asas hukum adat, yang menggambarkan unsur kekeluargaan, dapat diambil untuk dijadikan hukum nasional.

- Hukum nasional sendiri dengan hukum asing. Pada hukum nasional terdapat kekeurangan. Apabila ada keinginan untuk mengambil hukum asing/negara lain apakah hukum asing itu cocok dan sesuai dengan kepentingan nasional.

\section{Kesimpulan}

Berdasarkan uraian tersebut di atas, kiranya hakim dalam menjalankan kewajibannya memutuskan perkara yang dihadapinya apabila Peraturan Perundangan-undangan tidak ada, maka menurut IImu Hukum hakim dapat melakukan konstruksi hukum dan interpretasi hukum. Akan tetapi dalam melakukan Konstruksi Hukum dan Interpretasi Hukum tersebut terutama dalam 
perkara-perkara di luar hukum pidana, karena dalam hukum pidana lebih mengutamakan kepastian hukum yang berdasarkan kepada hukum tertulis dalam Peraturan Perundang-undangan. 


\section{Daftar Pustaka}

\section{Literatur}

C.S.T. Kansil, Pengantar IImu Hukum dan Tata Hukum Indonesia Jilid I Pengantar IImu Hukum (Semester Ganjil), Balai Pustaka, Jakarta, 1992.

Peter Mahmud Marzuki, Pengantar Ilmu Hukum, Kencana Prenada Group, Jakarta, 2009.

Mochtar Kusumaatmadja dan Arip B. Shidarta, Pengantar IImu Hukum, Suatu Pengenalan Pertama Ruang Lingkup Berlakunya IImu Hukum, Alumni, Bandung, 2000.

Satjipto Rahardjo, IImu Hukum, PT Citra Aditya Bakti, Bandung, 1996.

Ahmad Sanusi, Pengantar IImu Hukum dan Pengantar Tata Hukum Indonesia (PIH dan PTHI), Tarsito, Bandung, 1991.

Yudha Bhakti Ardiwisastra, Penafsiran dan Konstruksi Hukum, Alumni, Bandung, 2000.

R. Soeroso, Pengantar Ilmu Hukum, Sinar Grafika, Jakarta, 1993.

E. Utreht, Pengantar Dalam Hukum Indonesia.

\section{Perundang-undangan}

Undang-undang Republik Indonesia Nomor 48 Tahun 2009 tentang Kekuasaan Kehakiman. 